\title{
Construction of Activity-Based Costing System for Express Enterprises
}

\author{
Lele Wang \\ Xi'an International University, Xi'an, Shaanxi, China
}

Keywords: Activity-Based Costing; Express Enterprises; Cost Driver.

\begin{abstract}
Through the above-mentioned activity-based cost centers, according to the activity consumption of each business or product of express delivery, the enterprise consumption can be allocated through a reasonable causal relationship, and finally a more accurate cost of single business, customer or product can be obtained. Using traditional cost accounting methods to allocate the consumption of enterprises to the final cost object with a single cost driver will distort the cost, which will eventually lead to the wrong business decisions made by enterprises due to the wrong cost information. In this paper, according to the characteristics of express enterprises, we study the common business process of express enterprises. Based on the basic theory and method of activity-based costing, we divide seven basic activity centers of express enterprises, analyze the specific activity and cost drivers of each center, and build a complete activity-based costing system for express enterprises.
\end{abstract}

\section{Introduction}

From the perspective of the characteristics and nature of the cost of express delivery industry, indirect cost accounts for a large proportion of the cost of express delivery industry. Express business mainly focuses on small quantities of goods, and customers are geographically dispersed. In the business operation process, a large number of transit centers will be used to integrate goods to reduce costs. In this case, the traditional cost accounting method gradually loses the accuracy and even accuracy, which leads to the lack of accurate pricing basis for express companies, and can not find a reasonable method and way in cost control.

\section{Cost Characteristics of Express Enterprises}

Express cost accounting is the premise and basis for enterprises to understand the resources consumed by their own express system operation, The reason why enterprises don't understand their own express cost lies in the method of express cost accounting. In the traditional cost accounting of enterprises, the single cost driver is still used to calculate the cost of express delivery. Because of the characteristics of small batch in express enterprises, the final cost objects share a high proportion of cost under different operations in the whole business process.So, a single cost driver can not effectively solve the problem of indirect cost allocation. In other words, the main feature of the cost of express delivery enterprises is the large proportion of indirect cost.

Because of the large proportion of indirect cost in express enterprises, the cost accounting of 
express enterprises is mainly the apportionment of indirect cost. The inaccuracy of allocation will lead to wrong decision. In order to adapt to the high proportion of indirect cost and the diversification of product batch, express enterprises should adopt activity-based costing to account for the express cost.

\section{Cost Accounting Principle of Activity-Based Costing}

The basic principle of activity-based costing can be summarized as: product consumes activity, activity consumes resources. The resource consumption of the final cost object is mainly calculated according to the consumed activities in the process of producing the final cost object. Activity based costing mainly emphasizes the distribution of indirect costs, which should be linked with the activities in the production and sales process, not based on the production and the scale related to the production. Its ultimate goal is to distribute the costs in the actual services and products according to the causal relationship. Through activity-based costing, the causal relationship between resource consumption and the final cost object is constructed with activity as the intermediary, and then through this causal relationship, resources are allocated to the final cost object through activity.

The key of activity-based costing is to build activity center or activity base, and to analyze the cost drivers of each activity in detail. According to the application experience of Activity-Based Costing in Japan, activity-based costing can be divided into batch driven activity, quantity driven activity and exclusive activity. Diversified cost drivers make the final cost allocation more reasonable, and also make the final cost object cost accounting more accurate.

\section{The Rationality of Activity-Based Costing in the Cost Accounting of Express Enterprises}

The traditional cost accounting method makes it difficult for express companies to clearly understand the cost of their business activities, so they can not effectively manage their business activities. This not only reduces the competitiveness of enterprises, but also hinders the rapid development of express enterprises. The activity-based costing method is well adapted to the personalized, scientific, and diverse services of express enterprises. It can not only improve customer satisfaction to promote sales, but also improve profits to enhance enterprise reputation, so that express enterprises have a certain position in the competitive market.

For those express companies with complex and diversified express business and high proportion of indirect costs in the cost of express business, activity-based costing is used for accounting. On the one hand, it improves the standard of indirect cost allocation, and on the other hand, it can make $\mathrm{ABC}$ meet the accuracy of cost information. It is very necessary for those express companies whose express business is complex and diversified, and whose indirect costs account for a high proportion of the cost of express business to change the activity-based costing method for accounting. This can not only improve the standard of indirect cost allocation, but also get accurate cost information.

Activity-based costing is based on multiple allocation, which links financial variables and non-financial variables. This not only improves the correlation between financial variables and the actual consumption cost of products, but also provides relatively accurate product cost information under the activity-based costing. In the increasingly competitive situation of express enterprises, traditional cost accounting has long been unable to meet people's diversified needs. In this way, activity-based costing makes up for many information loopholes, accelerates the effective cost control of express enterprises, and has a great impact on management decisions.

\section{Construction of Express Enterprise Activity Center}

The core of establishing the activity-based costing system of express enterprises is to build the 
activity center of express enterprises. The basic idea of constructing the activity center is to build the basic activity center according to the main operation procedures of express enterprises, and then decompose every operation process of the basic activity center to build the activity Library under different activity centers.

The main operation procedures of express delivery enterprises are: receiving, arrival, unloading, sorting, loading and shipment. Table 1 shows the main operation processes of an express enterprise:

Table 1. Main Operation Processes in an Express Enterprise

\begin{tabular}{lllllll}
\hline Operations & $\begin{array}{l}\text { Activity } \\
\text { center } 1\end{array}$ & $\begin{array}{l}\text { Activity } \\
\text { center } 2\end{array}$ & $\begin{array}{l}\text { Activity } \\
\text { center } 3\end{array}$ & $\begin{array}{l}\text { Activity } \\
\text { center } 4\end{array}$ & $\begin{array}{l}\text { Activity } \\
\text { center } 5\end{array}$ & $\begin{array}{l}\text { Activity } \\
\text { center } 6\end{array}$ \\
\hline & Arriva & Unloading & sorting & loading & shipment \\
\hline
\end{tabular}

It can be seen from table 1 that in general, there are six basic activity centers of express enterprises, which are divided into receiving activity center, arrival activity center, unloading activity center, sorting activity center, loading activity center and shipping activity center according to the operation processes. Next, in this article,I will analyze these six activity centers in turn, and build the activity-based costing system of express enterprises according to the specific operation procedures of each activity center.

6. Construction of Accounting System for Each Activity Center

6.1 Construction of Accounting System of Receiving

Table 2. Receiving Activity Cost Accounting System

\begin{tabular}{|c|c|c|c|c|}
\hline & Activity & Cost driver & $\begin{array}{c}\text { Cost } \\
\text { (Payment form) }\end{array}$ & Sharing cost \\
\hline & $\begin{array}{c}\text { Receipt } \\
\text { preparation }\end{array}$ & Preparatory work & Labor cost & \multirow{11}{*}{$\begin{array}{l}\text { Labor cost } \\
\text { Deprecia-tion } \\
\text { of equipment }\end{array}$} \\
\hline & $\begin{array}{c}\text { Order } \\
\text { confirmation }\end{array}$ & Order number & Service Charge & \\
\hline & $\begin{array}{l}\text { Door-to-door } \\
\text { pick up }\end{array}$ & Quantity / mileage & Labor cost & \\
\hline \multirow{8}{*}{$\begin{array}{l}\text { Receiving } \\
\text { Activity } \\
\text { center }\end{array}$} & Data check & Required time & Labor cost & \\
\hline & $\begin{array}{l}\text { Weighing and } \\
\text { charging }\end{array}$ & Mechanical hours & $\begin{array}{l}\text { Depreciation of } \\
\text { equipment }\end{array}$ & \\
\hline & Cargo packaging & Time / pieces & Packing charges & \\
\hline & Waybill fill out & Frequency & Labor cost & \\
\hline & Cargo inspection & Number of boxes & Labor cost & \\
\hline & Freight collect & Value of goods & Service Charge & \\
\hline & $\begin{array}{c}\text { Terminal scan } \\
\text { upload }\end{array}$ & Mechanical hours & $\begin{array}{l}\text { Depreciation of } \\
\text { equipment }\end{array}$ & \\
\hline & $\begin{array}{c}\text { Document } \\
\text { delivery }\end{array}$ & Order number & maintenance cost & \\
\hline
\end{tabular}

The specific processes of receiving is: receiving preparation, order confirmation, on-site picking up, data inspection, weighing and billing, cargo packing, waybill filling, cargo inspection, 
express delivery, freight collection, terminal scanning and uploading, and delivery and payment and delivery. All activities of receiving, cost drivers and related costs of receiving are shown in Table 2.

\subsection{Construction of Accounting System of Arrival}

The specific processes of arrival operation is: receipt check, delivery of goods, inspection of quantity and quality classification of goods, warehousing handover, goods warehousing and listing, information registration and entry. When the goods arrive at the designated place, the relevant department responsible for receiving the goods must check whether the receipt of the bill of lading is consistent with the actual goods. When handing over the goods, the quality of the goods must be carefully checked, so as to facilitate the timely handling of the problems found. After checking the quality and quantity of the goods, and also the actual incoming goods and the receipt of the bill of lading, the warehousing handover should be carried out. After the goods arrive at the designated location and enter the warehouse, it is also very important to keep the goods. It is necessary to check and sort the goods according to the strict sorting system, and classify and summarize the goods, so as to make the whole process run smoothly. So, the arrival activities, cost drivers and cost (payment form) of each specific operation are listed in Table 3.

Table 3. Arrival Activity Cost Accounting System

\begin{tabular}{|c|c|c|c|c|}
\hline \multirow{10}{*}{$\begin{array}{c}\text { Arrival } \\
\text { activity } \\
\text { center }\end{array}$} & Activity & Cost driver & $\begin{array}{c}\text { Cost } \\
\text { (Payment form) }\end{array}$ & $\begin{array}{c}\text { Sharing } \\
\text { cost }\end{array}$ \\
\hline & Receipt check & Frequency & $\begin{array}{c}\text { Depreciation of } \\
\text { handling equipment }\end{array}$ & \multirow{9}{*}{$\begin{array}{l}\text { Labor cost } \\
\text { Deprecia-t } \\
\text { ion of } \\
\text { equipment }\end{array}$} \\
\hline & Hand over goods & $\begin{array}{c}\text { Number of towing } \\
\text { discs }\end{array}$ & Labor cost & \\
\hline & Cargo inspection & quality & Labor cost & \\
\hline & $\begin{array}{c}\text { Warehousing } \\
\text { transfer }\end{array}$ & Mechanical hours & $\begin{array}{l}\text { Depreciation of } \\
\text { equipment }\end{array}$ & \\
\hline & $\begin{array}{c}\text { Commodity } \\
\text { shelves }\end{array}$ & Mechanical hours & $\begin{array}{l}\text { Deprecia-tion of } \\
\text { equipment }\end{array}$ & \\
\hline & $\begin{array}{l}\text { Registration and } \\
\text { entry }\end{array}$ & Direct labor hours & Labor cost & \\
\hline & $\begin{array}{l}\text { Storage } \\
\text { arrangement }\end{array}$ & Mechanical hours & $\begin{array}{l}\text { Depreciation of } \\
\text { equipment }\end{array}$ & \\
\hline & Inventory & Direct labor hours & Labor cost & \\
\hline & Ordering & Mechanical hours & $\begin{array}{l}\text { Depreciation of } \\
\text { equipment }\end{array}$ & \\
\hline
\end{tabular}

\subsection{Construction of Accounting System of Unloading}

The specific processes of unloading operation is: unloading preparation, arrangement of storage location, arrangement of storage location, inspection of quality, timely feedback, exception handling, and normal unloading. In order to ensure the smooth progress of the whole unloading process, the relevant departments must make good preparation for unloading before the arrival of goods, arrange the storage location of the incoming goods, arrange the storage location, and reserve the storage location for the subsequent goods at the same time. In the processes of unloading, it is necessary to carefully check the quality of the incoming goods to see if there is any damage to the goods. In case of any abnormality of the goods, it is necessary to feed back the problem in time, and handle the abnormality of the goods, so that the abnormality of the goods can be handled in time to help the 
normal unloading. According to the above description, unloading activities, cost drivers and cost (payment form) of each specific operation are listed in Table 4.

Table 4. Unloading Activity Cost Accounting System

\begin{tabular}{|c|c|c|c|c|}
\hline \multirow{8}{*}{$\begin{array}{l}\text { Unloading } \\
\text { activity } \\
\text { center }\end{array}$} & Activity & Cost driver & $\begin{array}{c}\text { Cost } \\
\text { (Payment form) }\end{array}$ & $\begin{array}{c}\text { Sharing } \\
\text { cost }\end{array}$ \\
\hline & $\begin{array}{l}\text { Unloading } \\
\text { preparation }\end{array}$ & $\begin{array}{l}\text { Number of } \\
\text { workers }\end{array}$ & $\begin{array}{l}\text { Labor cost and } \\
\text { sorting cost }\end{array}$ & \multirow{3}{*}{ Labor cost } \\
\hline & $\begin{array}{l}\text { Arrange library } \\
\text { location }\end{array}$ & $\begin{array}{l}\text { Volume } \\
\text { Occupied }\end{array}$ & Labor cost & \\
\hline & $\begin{array}{c}\text { Finishing } \\
\text { library location }\end{array}$ & labor Hours & Finishing charge & \\
\hline & Quality testing & $\begin{array}{c}\text { Mechanical } \\
\text { hours }\end{array}$ & $\begin{array}{l}\text { Material loss cost } \\
\text { and technical cost }\end{array}$ & \multirow{2}{*}{$\begin{array}{c}\text { Depreciatio } \\
\text { n of } \\
\text { equipment }\end{array}$} \\
\hline & $\begin{array}{l}\text { Timely } \\
\text { feedback }\end{array}$ & $\begin{array}{l}\text { Problem } \\
\text { processing } \\
\text { interval }\end{array}$ & Information fee & \\
\hline & $\begin{array}{l}\text { exception } \\
\text { handling }\end{array}$ & Decision cost & $\begin{array}{l}\text { Management } \\
\text { expense }\end{array}$ & \multirow{2}{*}{$\begin{array}{l}\text { Information } \\
\text { fee }\end{array}$} \\
\hline & $\begin{array}{l}\text { Normal } \\
\text { handling }\end{array}$ & Frequency & $\begin{array}{l}\text { Depreciation of } \\
\text { handling } \\
\text { equipment }\end{array}$ & \\
\hline
\end{tabular}

\subsection{Construction of Accounting System of Sorting}

Table 5. Sorting Activity Cost Accounting System

\begin{tabular}{|c|c|c|c|c|}
\hline \multirow{7}{*}{$\begin{array}{c}\text { Sorting } \\
\text { activity } \\
\text { center }\end{array}$} & Activity & Cost driver & $\begin{array}{c}\text { Cost } \\
\text { (Payment form) }\end{array}$ & Sharing cost \\
\hline & $\begin{array}{c}\text { Sorting } \\
\text { preparation }\end{array}$ & Frequency & Labor cost & \multirow{6}{*}{$\begin{array}{l}\text { Labor cost } \\
\text { Maintenance } \\
\text { fee } \\
\text { Material cost } \\
\text { Freight }\end{array}$} \\
\hline & Address sorting & labor Hours & Labor cost & \\
\hline & Size sorting & labor Hours & Labor cost & \\
\hline & Scanning & $\begin{array}{l}\text { Mechanical } \\
\text { hours }\end{array}$ & Maintenance fee & \\
\hline & Quantity check & $\begin{array}{l}\text { Quantity of } \\
\text { goods }\end{array}$ & Material cost & \\
\hline & Delivering & Carry hours & Freight & \\
\hline
\end{tabular}

The specific processes of sorting operation is: sorting preparation, arrival address sorting, cargo size sorting, ticket by ticket scanning loading, verification of scanning quantity and delivery. Sorting is very important for logistics. It mainly classifies the parcels according to different standards. The receiver selects the code of the goods to be unloaded on the conveyor, scans the barcode with the machine in hand, and then unloads the sorted packages from the conveyor to the designated location. So if something goes wrong here, it will affect the final delivery. The receiver selects the code of the goods to be unloaded on the conveyor, scans the barcode with the machine in hand, and then unloads the sorted packages from the conveyor to the designated location. So if something goes wrong here, it will affect the final delivery. If the scanning quantity is inconsistent with the actual quantity in the sorting process, it will easily cause confusion in the logistics process 
and increase the logistics cost invisibly. In the process of sorting, the goods are not sorted according to the size, which makes it impossible to use the space reasonably and effectively in the loading process. According to the above description, sorting activities, cost drivers and cost (payment form) of each specific operation are listed in Table 5.

\subsection{Construction of Accounting System of Loading}

The specific processes of loading operation is: Cargo preparation, preparation before loading, outbound loading, loading information entry, locking the door, and information retention. In the process of loading, the goods must be prepared first to ensure orderly loading and improve loading efficiency. According to the above description, loading activities, cost drivers and cost (payment form) of each specific operation are listed in Table 6.

Table 6. Loading Activity Cost Accounting System

\begin{tabular}{|c|c|c|c|c|}
\hline \multirow{8}{*}{$\begin{array}{l}\text { Loading } \\
\text { activity } \\
\text { center }\end{array}$} & Activity & Cost driver & $\begin{array}{c}\text { Cost } \\
\text { (Payment form) }\end{array}$ & Sharing cost \\
\hline & Cargo preparation & Order number & Material cost & \multirow{7}{*}{$\begin{array}{l}\text { Labor cost } \\
\text { Material cost }\end{array}$} \\
\hline & $\begin{array}{l}\text { Loading } \\
\text { preparation }\end{array}$ & $\begin{array}{l}\text { Mechanical } \\
\text { hours }\end{array}$ & $\begin{array}{l}\text { Depreciation of } \\
\text { equipment }\end{array}$ & \\
\hline & $\begin{array}{c}\text { Preparation before } \\
\text { loading }\end{array}$ & $\begin{array}{l}\text { Quantity of } \\
\text { goods }\end{array}$ & $\begin{array}{l}\text { Warehouse rental } \\
\text { fee }\end{array}$ & \\
\hline & Shipment loading & labor hours & Labor cost & \\
\hline & Information entry & labor hours & $\begin{array}{c}\text { Order processing } \\
\text { fee }\end{array}$ & \\
\hline & Locking door & $\begin{array}{l}\text { Mechanical } \\
\text { hours }\end{array}$ & Technical fee & \\
\hline & $\begin{array}{l}\text { Information } \\
\text { retention }\end{array}$ & labor Hours & Information fee & \\
\hline
\end{tabular}

\subsection{Construction of Accounting System of Shipment}

The processes of shipment operation includes: personnel and vehicle condition inspection, delivery document inspection, loading, quantity verification, and goods delivery. After the driver confirms that the information is correct, the goods will be sent to the destination as soon as possible. According to the above description, shipment activities, cost drivers and cost (payment form) of each specific operation are listed in Table7.

Table 7. Shipment Activity Cost Accounting System

\begin{tabular}{ccccc}
\hline & Activity & Cost driver & $\begin{array}{c}\text { Cost } \\
\text { (Payment form) }\end{array}$ & Sharing cost \\
\cline { 2 - 4 } $\begin{array}{c}\text { Shipment } \\
\text { activity } \\
\text { center }\end{array}$ & Vehicle inspection & labor hours & Freight & $\begin{array}{c}\text { Management } \\
\text { expense }\end{array}$ \\
& Documents inspection & labor hours & $\begin{array}{c}\text { Labor cost } \\
\text { Depreciation of } \\
\text { equipment }\end{array}$ & Fuel and power \\
& Loading & Required time & costs & Various losses \\
& Verify quantity & labor hours & Labor cost & Direct labor cost \\
\hline
\end{tabular}


Through the above-mentioned activity-based cost centers, according to the activity consumption of each business or product of express delivery, the enterprise consumption can be allocated through a reasonable causal relationship, and finally a more accurate cost of single business, customer or product can be obtained.

\section{References}

[1] Baldwin and Clark.Mangaing an Ang of Modularity[J]. Harvard Business Review,1997,75(5)

[2] Naguney,June Dong Ding Zhang .A supply chain network equilibrium mode[J].Transportation Research Part E.2002(38):281-303

[3] Shao Ruiqing,Discussion on logistics cost accounting method of logistics enterprises [M], research on economy and management,2014.8

[4] Ye Linhu. Application of Activity-Based Costing in Chinese enterprises [J]. Business research. 2014 